\title{
PEREMPUAN DI SEKTOR PUBLIK DALAM PERSPEKTIF ISLAM (Pandangan Progresif Rahmah El-Yunusiyah Dalam Kepemimpinan Sebagai Ulama Dan Pelopor Pendidikan Muslimah Indonesia) \\ Prilia Ulandari ${ }^{1}$ \\ priliaulandari@gmail.com
}

\begin{abstract}
Abstrak: Pandangan Rahmah El-Yunusiyah dapat diimplementasikan untuk menjadikan perempuan setara dengan laki-laki dalam segala akses kehidupan di ruang domestic maupun public, hal ini bukan dalam rangka untuk melawan laki-laki. Sama sekali tidak. Mereka dibutuhkan untuk bersama kaum laki-laki membangun negara dan bangsa ini demi terwujudnya cita-cita bersama, keadilan, kemajuan dan kesejahteraan. Mereka dibutuhkan untuk memberi makna-makna baru atas keadilan dan kemanusiaan. Bangunan relasi antara laki-laki dan perempuan adalah bangunan relasi kesalingan, sebagaimana dijelaskan dalam Al-Qur'an dan Sunnah.
\end{abstract}

Kata kunci: Rahmah El-Yunusiyah, Kepemimpinan, Ulama Perempuan, Pendidikan Perempuan

\section{PENDAHULUAN}

Sejak awal abad 20 sampai hari ini kita menyaksikan upaya-upaya baru yang menggugat keterpinggiran perempuan. Lebih dari itu perempuan-perempuan Indonesia hari ini tengah mengalami problem besar: kekerasan terhadap perempuan dan anak dalam berbagai bentuknya, dan berlangsung hampir di semua ruang dan waktu kehidupan. Mereka harus dibebaskan dari situasi ini dan harus dicerdaskan. Terbukanya akses pendidikan yang setara bagi laki-laki dan perempuan dalam kehidupan demokrasi yang berkembang sehat akan membuka ruang bagi kaum perempuan untuk meraih kemajuan, keadilan dan kesejahteraan bersama. Kecerdasan dan kemajuan perempuan adalah kecerdasan dan kemajuan untuk semua.

\footnotetext{
${ }^{1}$ Penulis merupakan mahasiswa Program Studi Pendidikan Agama Islam Program Pascasarjana Institut Agama Islam Negeri Batusangkar
} 
Sejarah orang-orang besar adalah sejarah perempuan-perempuan. Mereka dilahirkan dan dididik oleh seorang perempuan. Sebagian para perempuan itu adalah ulama. Keulamaan perempuan dan peran mereka sebagai guru para ulama laki-laki telah hadir sejak awal sejarah Islam. Sebagian mereka menjadi guru para sahabat lakilaki. Antara lain: Aisyah bint Abu Bakar. Ia disebut sebagai "A 'lam al-Nas wa Afqah al-Nas wa Ahsan al-Nas Ra'yan fi al- 'Ammah"'(orang paling pandai, paling faqih dan paling baik di antara semua orang). Al-Dzahabi dalam "Siyar A'lam al-Nubala" (riwayat hidup ulama-ulama cerdas) mengatakan: "tidak kurang dari 160 sahabat lakilaki mengaji pada Siti Aisyah". Sebagian ahli hadits lain menyebut: murid-murid Aisyah ada 299 orang: 67 perempuan dan 232 laki-laki. Umm Salamah binti Abi Umayyah mengajar 101 orang: 23 perempuan dan 78 laki-laki. Hafshah binti Umar: 20 murid: 3 perempuan dan 17 laki-laki. Hujaimiyah al-Washabiyyah: 22 murid laki-laki. Ramlaha bint Abi Sufyan: 21 murid: 3 perempuan dan 18 laki-laki. Fatimah binti Qais: 11 murid laki-laki. (Muhammad al-Habasy, Al-Mar'ah Baina al-Syari'ah wa al-Hayah, dalam Muhammad, 2014: 4)

Pada periode berikutnya sejarah mencatat nama-nama perempuan ulama yang cemerlang, beberapa di antaranya adalah Sayyidah Nafisah (w. 208 H), cicit Nabi. Namanya dikenal sebagai perempuan cerdas, sumber pengetahuan ke-Islaman (Nafisah al-' $\mathrm{Ilm}$ ), pemberani, sekaligus 'abidah zahidah (tekun menjalani ibadah). Ia adalah guru Imam al-Syafi'I dan kemudian Imam ahmad bin Hanbal. Imam al-Syafi'i adalah "ulama yang paling sering bersamanya dan mengaji kepadanya, padahal ia seorang ahli fiqh besar (Muhammad, 2014: 4).

Fakta-fakta sejarah dalam peradaban awal Islam ini menunjukkan dengan pasti betapa banyak perempuan yang menjadi ulama, cendikia dan intelektual, dengan beragam keahlian dan dengan kapasitas intelektual yang relatif sama dengan bahkan sebagian mengungguli ulama laki-laki. Fakta ini dengan sendirinya telah menggugat anggapan banyak orang bahwa akal dan intelektualisme perempuan lebih rendah dari akal intelektualisme laki-laki. Islam memang hadir untuk membebaskan penindasan 
dan kebodohan menuju perwujudan kehidupan yang berkeadilan dan memajukan ilmu pengetahuan untuk semua manusia: laki-laki dan perempuan.

Para ulama perempuan tersebut telah mengambil peran-perannya sebagai tokoh agama, tokoh ilmu pengetahuan, tokoh politik dan tokoh dengan moralitas yang terpuji. Aktifitas mereka tidak hanya dari dan dalam ruang domestik (rumah) melainkan juga dalam ruang publik politik dalam arti yang lebih luas. Mereka bekerjasama dengan ulama laki-laki membangun peradaban Islam.

Dari mereka kemudian lahirlah para ulama dan aktifis perempuan di banyak negara muslim. Tidak sedikit para ulama perempuan tampil kembali ke panggung sejarah. Pengetahuan mereka dalam bidang ilmu-ilmu agama (Islam) sangat mendalam dan luas. Beberapa diantaranya adalah Huda Sya'rawi, Aisyah Taymuriyah, Batsinah, Nabawiyah Musa, Zainab alGhazali, Aisyah Abdurrahman bint Syathi, Asma Barlas, Aminah Wadud, Asma al-Murabith dan masih banyak lagi (Muhammad, 2014: 7). Mereka mengajak para ulama untuk melakukan reinterpretasi dan rekonstruksi atas wacana keagamaannya dengan melihat fakta-fakta perkembangan dan perubahan sosial, budaya dan politik yang tidak bisa dilawan.

Di Indonesia, kita juga mengenal sejumlah ulama perempuan, antara lain yang populer adalah Rahmah el-Yunusiyah, pendiri Perguruan Diniyah Putri, Padang Panjang. Dia memperoleh gelar doctor honoris Causa dari Universitas Al-Azhar, Kairo. Rahmah El-Yunusiyah berpendapat bahwa wanita itu harus mendapatkan akses pendidikan, sebagaimana kaum laki-laki mendapatkan kesempatan yang sama (Isnaini, 2016: 3). Hak untuk mempunyai ilmu pengetahuan dan pendidikan antara perempuan dan laki-laki adalah sama. Karena pada dasarnya dalam Al-Qur'an juga telah banyak menjelaskan dan memberikan ruang terhadap hak-hak kemanusiaan perempuan salah satunya berupa hak asasi pendidikan. Sesungguhnya keluhuran dan keunggulan manusia itu didasarkan atas kebaikan budinya yang diperoleh melalui pendidikan. Dan begitulah ajaran Islam menaruh perhatian yang sangat besar terhadap umatnya yang menuntut ilmu dengan tidak membedakan apakah itu laki-laki atau perempuan. 
Pada masanya sistem pendidikan sebelumnya yang bercorak tradisional masih kurang memberikan akses bagi perempuan. Selain itu kurang penekanannya terhadap akses untuk masuk dunia kerja dan kesempatan lain. Dalam situasi masyarakat yang pada saat itu sedang berkembang inilah Rahmah El-Yunusiyah tergugah hatinya untuk berkiprah. Ia menaruh perhatian khusus terhadap pendidikan kaum perempuan. Karena Ia menyadari bahwa pendidikan menjadi sarana utama bagi peningkatan posisi kaumnya (Isnaini, 2016: 3). Dan pada saat ini, bila melihat keadaan perempuan sekarang yang telah mendapatkan tempat berkiprah dalam sektor publik, lingkungan sosial dan memperoleh hak pendidikan tidak terlepas dari perjuangan ulama perempuan Islam nusantara, Syaikhah Rahmah El-Yunusiah.

Sejarah banyak mencatat kiprahnya dalam memperjuangkan dan mendedikasikan seluruh hidupnya untuk pendidikan perempuan Indonesia. Bermula dari keprihatinannya terhadap nasib perempuan di jamannya yang disebabkan adanya ketidaksetaraan kesempatan belajar antara laki-laki dan perempuan. Maka dari itu, perjuangannya untuk perempuan diwujudkannya dengan pendirian madrasah khusus perempuan yang dinamai Madrasah Diniyyah putri di tanah Minangkabau sebagai pembaharuan pendidikan Islam bagi perempuan. Makalah ini akan mencoba mengulas perempuan di sektor publik dalam perspektif Islam dari pandangan progresif Rahmah El-Yunusiyah dalam kepemimpinan sebagai ulama dan pelopor pendidikan muslimah Indonesia pada Perguruan Diniyah Puteri-nya.

\section{PERJALANAN HIDUP RAHMAH EL-YUNUSIAH}

\section{Rahmah El-Yunusiyyah dan Keluarga}

Rahmah el-Yunusiyah lahir di sebuah rumah gadang jalan Lubuk Mata Kucing, Kanagarian Bukit Surungan, Padang Panjang. Pada tanggal 29 Desember 1900 M, bertepatan dengan tanggal 1 Rajab 1318 H, dari keluarga Syekh Muhammad Yunus dan Rafi'ah. Terlahir sebagai anak terakhir dari lima bersaudara yaitu Zainuddin Labay (1890-1924 M), Mariah (1893-1972 M), Muhammad Rasyad (1895-1956 M), dan Rihanah (1898-1968 M) (Nuraida, 1990: 40). 
Ayahnya bernama Syekh Muhammad Yunus (1846-1906 M) adalah seorang ulama besar dan seorang Qadli di negeri Pandai Sikat dan pimpinan Tarekat Naqsabandiyah al-Khalidiyah. Selain itu Syekh Muhammad Yunus juga ahli ilmu falak dan hisab. Syekh Muhammad Yunus pernah menuntut ilmu di tanah suci Mekkah selama 4 tahun. Kakeknya ialah Syeikh Imaduddin, yang juga terkenal sebagai ulama ahli ilmu falak dan tokoh tarekat Naqsabandiyyah di Minangkabau. Yaitu ulama yang masih ada darah keturunan dengan pembaharu Islam yang juga seorang tokoh Paderi bernama Tuanku Nan Pulang di Rao.

Adapun ibunda Rahmah el-Yunusiyah yang biasa disebut Ummi Rafi'ah, nenek moyangnya berasal dari negeri Langkat, Bukittinggi Kabupaten Agam dan pindah ke bukit Surungan Padang Panjang pada abad XVIII M yang lalu. Ummi Rafi'ah masih berdarah keturunan ulama, empat tingkat diatasnya masih ada hubungan dengan mamak Haji Miskin, sang pembaharu gerakan Paderi. Dari silsilah keturunan Rahmah El-Yunusiyah Nampak bahwa ia berasal dari keturunan ulama. Dalam usia enam belas tahun Rahmah menikah dengan seorang alim dan mubaligh bernama Haji Bahauddin Lathif dari Sumpur Padang Panjang. Perkawinan ini tidak berlangsung lama, hanya enam tahun, pada tahun 1922 keduanya bercerai atas kehendak kedua belah pihak dan selanjutnya menganggap sebagai dua orang bersaudara (Hamruni, 2004: 3).

Dari perkawinan ini Rahmah tidak mempunyai anak. Sejak perceraian tersebut, ia tidak bersuami lagi. Rupanya hal ini yang memberikan faedah kepadanya, sehingga ia dapat menempatkan seluruh hidupnya kepada perguruan yang didirikannya. Rahmah el-Yunusiah menjalani hidupnya dengan perjuangan untuk memajukan kaum perempuan. Rahmah meninggal dunia pada tanggal 9 Zulhijjah 1388 Hijriah atau tanggal 26 Februari 1969 M di rumahnya di Padang Panjang. Jenazahnya dikuburkan di perkuburan keluarga di samping rumahnya yang juga di samping perguruan yang ia dirikan di pinggir jalan Lubuk Mata Kucing (Hamruni, 2004: 4). 
Rahmah El-Yunusiyah berasal dari keluarga taat dalam masalah keagamaan. Kondisi inilah nantinya yang akan berpengaruh pada pembentukan pribadi Rahmah. Ia menjadi orang yang cinta mendalami ajaran-ajaran agama serta memiliki perhatian sangat besar terhadap kondisi masyarakat pada masanya khususnya kalangan kaum perempuan. Karena itu pendidikan yang diperoleh Rahmah pada prinsipnya banyak dari keluarganya sendiri yang memang sangat menaruh perhatian pada masalahmasalah keagamaan.

\section{Rahmah El-Yunusiah dan Pendidikan}

Syekh Haji Muhammad Yunus, ayah dari Rahmah telah meninggal dunia pada tahun 1906 M, ketika itu Rahmah masih kanak-kanak sehingga ia tidak banyak mendapatkan pendidikan dari ayahnya. Ia dibesarkan oleh ibu dan diasuh oleh kakaknya yang telah berumah tangga. Sejak kecil, Rahmah tidak pernah bersekolah di Sekolah Dasar (Sekolah Desa, Gubernemen) yang memang telah ada juga di Minangkabau pada masa kanak-kanaknya dulu. Walaupun saat itu juga sudah ada sekolah Bumiputera tingkat pertama di Minangkabau. Meskipun begitu, ia banyak belajar dari lingkungannya. Tetapi, Rahmah yang sudah menjadi yatim semenjak kanak-kanak itu mendapatkan pendidikan terbaik dari keluarga dan murid-murid ayahnya (Alim, 2016: 2).

Engku Uzair Malim Batuah yang juga murid ayah Rahmah mengajarinya membaca Al-Qur'an semenjak usianya enam tahun. Ketika usianya delapan tahun, Rahmah dituntun tulis-baca huruf latin oleh kakaknya Zainuddin Labay El-Yunusiy dan Muhammad Rasyad yang pernah belajar di Sekolah Desa. Umi Rafi'ah ibunya, juga ikut mengajari Rahmah berhitung dengan angka-angka Arab (angka Melayu). Kepandaian membaca dan menulis ini, kemudian hari sangat menolongnya dalam menambah ilmu pengetahuannya, karena ia termasuk salah seorang anak yang senang membaca. Sejak usia dini Rahmah juga secara rutin dan aktif mengikuti pengajianpengajian dari surau ke surau untuk memambah pengetahuannya di bidang agama (Alim, 2016: 3). 
Setelah Diniyah School didirikan kakaknya pada tanggal 10 Oktober 1915, Rahmah ikut belajar di perguruan ini. Ia banyak memperoleh pengetahuan praktis yang berkenaan dengan pergaulan, terutama pergaulan antara murid-murid perempuan dan laki-laki serta watak manusia yang berbagai ragam. Dahulu Rahmah jarang atau tidak diperkenankan bergaul dengan anak laki-laki, tapi setelah ia bersekolah di perguruan ini, ia dapat bergaul dengan murid laki-laki. Ia dapat bertukar fikiran dengan mereka baik mengenai hukum Islam, sosial, budaya dan pergaulan (muamalah). Dari pengenalan berbagai macam watak manusia ini ia mulai menyadari dirinya dan keadaan masyarakat lingkungannya, terutama masyarakat atau kaum perempuan, yaitu mereka yang tidak memperoleh kesempatan menuntut ilmu sebagaimana yang dialaminya (Hamruni, 2004: 6).

Selama ia menjadi siswa Diniyah School, ia dapat menuntut ilmu dengan baik dan dengan kecerdasannya mendorong Rahmah untuk bersikap kritis, tidak puas dengan sistem koedukasi pada Diniyah School yang kurang memberikan penjelasan terbuka kepada siswa puteri mengenai persoalan khusus perempuan. Rasa ketidakpuasannya ini dibicarakan dengan ke-tiga temannya sesama perempuan, yaitu Rasuna Said dari Maninjau yang kemudian hari namanya diabadikan sebagai Pahlawan Nasional, Nanisah dari Bulaan Gadang Banuhampu, dan Jawana Basyir (Upik Japang) dari Lubuk Agung. Mereka berempat bersepakat untuk membentuk kelompok belajar. Rahmah mengajak ketiga temannya ini untuk menambah ilmu agama secara mendalam di luar perguruan di antaranya di Surau Jembatan Besi. Surau Jembatan Besi yang dipelopori oleh Syekh Haji Abdullah Ahmad ini kelak menjadi PGAI (Nata, 2005: 29).

Tampaknya di Surau Jembatan Besi inilah Rahmah bertemu dengan sosok Haji Abdoel Karim Amrullah (ayahanda dari Buya Hamka), dan memintanya untuk mengajarinya berbagai disiplin ilmu agama secara privat di rumahnya di Gatangan. Di sini ia memperdalam pengajian mengenai masalah agama dan perempuan, di samping itu ia juga mempelajari bahasa Arab, fiqih, ushul fiqih, tasawuf, ilmu falak, sejarah Islam, tauhid, dan tafsir Al-Qur'an. Rahmah juga belajar dari ulama minang lainnya seperti, Tuanku Muda Abdul Hamid Hakim (pimpinan sekolah 
Thawalib Padang Panjang), Syekh Muhammad Jamil Jambek, Syekh Abdul Latif Rasjidi, dan Syekh Daud Rasjidi. Ia baru merasakan adanya kepuasan dan telah menemukan apa yang dicarinya selama ini (Mantovani, 2015: 4).

Semangat Rahmah dalam mempelajari ilmu selain agama dan bahasaArab, terus berkobar. Rahmah juga belajar gimnastik (olahraga dan senam) dari seorang guru pada Meisjes. Normal-School (sebuah pendidikan guru) di Guguk Malintang yaitu Mej. Oliver (nona Olvier). Kemudian ia juga mempelajari cara bertenun tradisional, yakni: bertenun dengan menggunakan alat tenun bukan mesin yang pada masa itu banyak dilakukan oleh masyarakat Minangkabau.

Ia mendatangi beberapa pusat pertenunan rakyat seperti Pandai Sikat, Bukittinggi dan Silungkang. Ilmu bertenun ini ia lengkapi dengan belajar jahitmenjahit. Ke dua ilmu ini yakni: bertenun dan jahit-menjahit dimasukkannya ke dalam kurikulum perguruannya. Mengenai ilmu-ilmu umum seperti ilmu hayat, ilmu alam, ilmu bumi dan lainnya, ia pelajari sendiri dari buku. Kemudian semua ilmu yang ia peroleh dengan kursus atau belajar sendiri ini ia ajarkan kepada murid-muridnya, kelak setelah ia mendirikan sekolah Diniyah Puteri tahun 1923 (Hamruni, 2004: 7).

Diusianya yang ke-23 tahun, Rahmah mendirikan Madrasah lil-banat yang menjadi cikal bakal Diniyyah Putri School. Setelah tujuh tahun mengembangkan sekolahnya, Rahmah tertarik untuk menambah pengetahuan dan keterampilan yang kelak dibutuhkan oleh kaum muslimah. Sekitar tahun 1931-1935, ia mengikuti kursus ilmu kebidanan di RSU Kayu Tanam dan mendapat izin praktek / ijazah bidan dari dokter. Dalam bidang kebidanan ini ia juga mendapat bimbingan yang mula-mula diberikan dari kakak ibunya Kudi Urai, seorang bidan yang menolong kelahiran dirinya dan Sutan Syahrir (Mantan Perdana Menteri RI).

Selain itu, ia belajar ilmu kesehatan dan pertolongan pertama pada kecelakaan (P3K) dari enam orang dokter yang juga gurunya dalam kebidanan: dokter Sofyan Rasyad dan dokter Tazar di rumah sakit umum Kayu Tanam (mendapat izin praktek dan ijazah dengan kedua dokter ini), dokter A. Saleh di RSU Bukittinggi, dokter Arifin dari Payakumbuh, dan dokter Rasjidin dan dokter A. 
Sani di Padang Panjang. Untuk mendalami praktek kebidanan dan ilmu kesehatan ini ia belajar sambil praktek di RSU Kayu Tanam (Hamruni, 2004: 6).

Tempaan pengalaman kehidupan telah membentuk kepribadian Rahmah menjadi seorang yang tabah, penuh toleransi dan teguh pendirian, serta berkeimanan yang kuat, akidah yang tangguh dan ketakwaan yang kokoh. Untuk mewujudkan citacitanya dan bila menghadapi kesulitan, dia semakin bertaqarrub dan meningkatkan ibadah kepada Allah.

Demikianlah dilihat dari usaha Rahmah menuntut ilmu, Pada dasarnya Rahmah memperoleh pendidikan atas inisiatifnya sendiri, pada saat pendidikan formal bagi kaum perempuan hanya tersedia bagi segelintir orang. Nampak bahwa hal tersebut merupakan menifestasi dari ketidakpuasannya terhadap pengetahuan yang diperolehnya dalam masalah perempuan. Ia juga merasa kecewa melihat kaumnya tidak bisa memperoleh pendidikan yang memadai sebagaimana yang dialaminya. Padahal Rahmah meyakini pentingnya peranan pendidikan sebagai salah satu jalan untuk mengangkat derajat kaum perempuan.

\section{CITA-CITA IDEAL AL QUR'AN TENTANG PEREMPUAN}

Mahmud Syaltut mengatakan bahwa tabiat kemanusiaan laki-laki dan perempuan hampir dikatakan dalam batasan yang sama. Allah telah menganugerahkan kepada perempuan sebagaimana menganugerahkan kepada laki-laki potensi yang cukup untuk memikul tanggung jawab kemanusiaan (Shihab, 2004: 7). Nabi Muhammad datang membawa angin perubahan di tengah kehidupan masyarakat Arab yang jauh dari nilai-nilai kemanusiaan. Nabi Muhammad datang membawa agama baru yang di dalamnya memuat prinsip-prinsip yang lebih egaliter dalam memperlakukan manusia sebagai manusia. Agama tersebut kemudian dikenal dengan Islam. Prinsip perubahan yang dibawa Nabi Muhammad dan Al-Quran di antaranya bisa dilihat dalam masalah relasi laki-laki dan perempuan. Jika kebiasaan dan budaya Arab pra-Islam memposisikan perempuan sebagai makhluk kelas dua, maka Alquran menempatkan prinsip kesetaraan sebagai basis epistemologisnya. Dalam beberapa ayat yang ada di 
dalamnya, Alquran menegaskan kesetaraan tersebut (Ilyas, 2006: 2). Al-Quran menjelaskan hal ini dalam surat Al-Ahzab (33:35) sebagai berikut.

"Sesungguhnya laki-laki dan perempuan yang muslim, laki-laki dan perempuan yang mukmin, laki-laki dan perempuan yang tetap dalam ketaatannya, laki-laki dan perempuan yang benar, laki-laki dan perempuan yang sabar, laki-laki dan perempuan yang khusyuk, laki-laki dan perempuan yang bersedekah, laki-laki dan perempuan yang berpuasa, laki-laki dan perempuan yang memelihara kehormatannya, laki-laki dan perempuan yang banyak menyebut (nama) Allah, Allah telah menyediakan untuk mereka ampunan dan pahala yang besar".

Dari ayat di atas dapat dipahami bahwa kesetaraan antara laki-laki dan perempuan tidak perlu diragukan. Selain ayat di atas, Allah mejelaskan lebih lanjut di QS. Al-Isra / 17: 23 yaitu:

"Dan Tuhanmu telah memerintahkan supaya kamu jangan menyembah selain Dia dan hendaklah kamu berbuat baik pada ibu bapakmu dengan sebaikbaiknya. jika salah seorang di antara keduanya atau Kedua-duanya sampai berumur lanjut dalam pemeliharaanmu, Maka sekali-kali janganlah kamu mengatakan kepada keduanya Perkataan "ah" dan janganlah kamu membentak mereka dan ucapkanlah kepada mereka Perkataan yang mulia”.

Ayat di atas menjelaskan bahwa Allah lebih menegaskan perintahnya di sini dengan: pertama, Allah memerintahkan supaya hamba-Nya tidak mempersekutukanNya dengan sesuatu apapun yaitu dengan hanya memurnikan ketaatan pada-Nya. Kedua, setelah perintah menyembah Allah dalam ayat ini, susudah itu Allah meminta hamba-Nya untuk "hendaklah kamu berbuat baik pada ibu bapakmu dengan sebaikbaiknya", dalam hal ini betapa mulianya kedudukan ibu sebagai perempuan dalam AlQur'an. Allah menganugerahkan ibu sebagai perempuan dengan memposisikannya menjadi urutan kedua setelah perintah untuk menyembah Allah.

Ayat di atas juga menggambarkan fenomena perempuan Islam, dalam hal ini menjelaskan kedudukan dan peran perempuan, bahwa perempuan merupakan tiang Negara, karena perempuanlah yang akan melahirkan penerus perjuangan bangsa ini, jadi supaya hal ini terwujudkan dengan baik perempuan harus diberikan potensi berupa pendidikan dan pengajaran berdasarkan Al-Qur'an dan Sunnah, dengan tujuan agar 
dapat menciptakan generasi "insan kamil” yang berakidah dan berakhlak mulia serta memiliki keimanan yang teguh, dan kesungguhan dalam mempraktikkan ajaran Islam agar berhasil menumbuhkan individu-individu "siap tempur", yang unggul secara mental maupun moralnya, dan pada gilirannya membentuk masyarakat madani yang Islami.

\section{PEREMPUAN DI SEKTOR PUBLIK DALAM PERSPEKTIF ISLAM}

\section{Kepemimpinan Perempuan Menurut Al Qur'an}

Kepemimpinan perempuan, terkait dengan persoalan ini Allah SWT. berfirman dalam surat an-Nisa (4):34.

"Kaum laki-laki itu adalah pemimpin bagi kaum wanita, oleh karena Allah telah melebihkan sebahagian mereka (laki-laki) atas sebahagian yang lain (wanita), dan karena mereka (laki-laki) telah menafkahkan sebagian dari harta mereka. sebab itu Maka wanita yang saleh, ialah yang taat kepada Allah lagi memelihara diri ketika suaminya tidak ada, oleh karena Allah telah memelihara (mereka). wanita-wanita yang kamu khawatirkan nusyuznya, Maka nasehatilah mereka dan pisahkanlah mereka di tempat tidur mereka, dan pukullah mereka. kemudian jika mereka mentaatimu, Maka janganlah kamu mencari-cari jalan untuk menyusahkannya. Sesungguhnya Allah Maha Tinggi lagi Maha besar".

Menurut penafsiran Ibn Katsir, kaum laki-laki adalah penanggung jawab terhadap kaum perempuan, yakni kepala, pemimpin, dan penguasa bagi kaum perempuan, serta memperbaiki (meluruskan) kaum perempuan bilamana terjadi ketimpangan. Hal demikian karena kaum laki-laki itu lebih utama dibandingkan dengan kaum perempuan sehingga predikat kenabian (nubuwwah) hanya dikhususkan bagi kaum laki-laki, dan demikian pula jabatan kepala Negara dan hakim.

Berbeda dengan Ibn Katsir, Quraish Shihab tidak menolak kepemimpinan perempuan selain di rumah tangga. Menurut Shihab uraian tentang ayat ini hanya fokus pada kepemimpinan rumah tangga sebagai hak suami. Dengan begitu istri tidak

memiliki hak kepemimpinan atas dasar sesuatu yang kodrati (given) dan yang diupayakan (nafkah) (Shihab, 2005: 346). Sekarang, persoalannya mungkinkah perempuan mengisi kepemimpinan di ruang publik? 
Pertama, berbicara hak berarti berbicara kebolehan (bukan anjuran, apalagi kewajiban). Ayat di atas tidak melarang kepemimpinan perempuan di ruang publik, karena konteksnya dalam kepemimpinan rumah tangga. Shihab mengungkapkan: Tidak ditemukan dasar yang kuat bagi larangan tersebut. Justru sebaliknya ditemukan sekian banyak dalil keagamaan yang dapat dijadikan dasar untuk mendukung hakhak perempuan dalam ranah publik. Salah satu yang dapat dikemukakan dalam kaitan ini adalah QS.at-Tawbah / 9 ayat 71:

"Dan orang-orang yang beriman, laki-laki dan perempuan, sebagian mereka adalah menjadi penolong bagi sebagian yang lain. Mereka menyuruh kepada yang makruf, mencegah kepada yang mungkar, melaksanakan shalat, menunaikan zakat, dan mereka taat kepada Allah dan Rasul-Nya. Mereka itu akan dirahmati Allah; sesungguhnya Allah Maha perkasa lagi Maha bijaksana".

Argumen ini sama dengan apa yang dikemukakan Justice Aftab Hussain bahwa prinsip yang mendasari kebolehan perempuan menjadi pemimpin di ruang publik adalah prinsip yang berlaku dalam segala hal adalah kebolehan, sampai ada dalil yang menunjukkan ketidakbolehan.

Kedua, di samping tidak di temukan dalam ayat-ayat al-Qur'an larangan bagi perempuan untuk menjadi pemimpin dalam ruang publik, hadis-hadis Nabi juga diam dari larangan itu. Menurut Mernissi untuk hal ini dalam pendidikan Islam, dilihat dari sisi nilai-nilai universal bias gender ini mengandung prinsip-prinsip keadilan, prinsip-prinsip egaliter, keharusan untuk saling menghargai dan menghormati orang lain dan sebagainya.

Diantaranya sebagaimana disebutkan dalam Al-Qur'an surat an-Nahl/16: 97; "Barangsiapa yang mengerjakan amal saleh baik laki-laki maupun perempuan dalam keadaan beriman, maka sesungguhnya akan Kami berikan kepadanya kehidupan yang baik”. Ayat serupa diantaranya disebutkan pada QS 4/Annisa: 124, QS 2/Al-Baqarah: 30, QS 49/al-hujurat: 13. Begitu juga di dalam hadis diantaranya Rasulullah bersabda: "Sesungguhnya Allah tidak melihat pisik dan 
rupamu, tetapi melihat hati dan amal perbuatanmu” (Hadis riwayat Muslim) (Shihab, 2005: 347).

Jadi menurut Alquran dan hadis, tidak ada perbedaan signifikan antara laki-laki dan perempuan kecuali dalam beberapa aspek yang mengharuskan berbeda. Pada prinsipnya Islam menyerukan adanya kemerdekaan, dan kesempatan yang sama antara laki-laki dan perempuan. Ini merupakan sebuah konsekuensi untuk mewujudkan nilai kemanusiaan dengan adanya pemerataan yang tidak bias gender.

\section{Pembelaan Pendidikan Islam terhadap Perempuan}

Dalam al-Qur'an maupun Hadis, Nabi bersabda, menuntut ilmu adalah kewajiban setiap muslim (Riwayat Ibn Majah, al-Baihaqi, dan Ibn Abd al-Barr). Jika ditelaah lebih lanjut, keduanya sama-sama memberikan pesan; pertama, orang yang beriman dan berilmu lebih mulia daripada yang tidak memilikinya, kedua, mencari ilmu diwajibkan bagi semua muslim, baik perempuan maupun lakilaki. Dan ketiga, tidak ada perbedaan nilai kemuliaan bagi siapapun yang berilmu, apakah ia perempuan atau laki-laki. Lantas, mengapa perempuan masih tertinggal?

Fenomena paling menarik dalam konteks wacana gender di dalam sejarah Islam, adalah munculnya tokoh perempuan sebagai faktor pendukung utama dalam proses risalah. Adalah Siti Khadijah istri Nabi, kedudukannya teramat penting dalam sejarah Islam atas perannya yang turut terlibat dalam proses kenabian Muhammad. Sebagai seorang saudagar yang membuatnya sangat mandiri memungkinkan mampu mengatur kehidupan kontemplatik suaminya selama proses menjelang pewahyuan (Baidan, 1999: 33). Dalam perspektif ini Khadijah layak bahkan seharusnya menjadi ikon dari seluruh isu kesetaraan gender dalam Islam.

Pada masa nubuwwah keseriusan Nabi terhadap proses pendidikan dan pemberdayaan masyarakat muslim ini, dimulai dengan didirikannya masjid sebagai institusi publik yang memiliki multi fungsi. Masjid pertama yang dibangun Nabi merupakan tempat ibadah sekaligus tempat pengaturan permasalahan sehari-hari. Pola manajemen pemerintahan yang masih general ini justru memiliki sisi-sisi positif, 
misalnya untuk mempermudah mobilisasi Nabi dalam berinteraksi dan mengatur umat tanpa menganggung kebutuhannya atas kehidupan berumah tangga, maka Nabi membangun tempat tinggal (mess) bagi para istrinya di dekat masjid sehingga mereka dapat saling berdiskusi satu-sama lain.

Pada masa Islam para perempuan memperoleh kebebasannya untuk mengekspresikan gagasan-gagasannya dan terdorong untuk berpartisipasi dalam kehidupan sosial. Kehidupan publik bagaikan panggung di mana antara perempuan dan laki-laki keduanya terlibat. Bahkan para perempuan berdiskusi dan berdebat dengan Nabi (Baidan, 1999: 36). Haiffa dalam Baidan (1999) mengingatkan bahwa Al Qur'an mendorong para perempuan untuk berbicara mengutarakan pemikirannya dan tidak untuk diam; kendati demikian justru pada saat ini para fundamentalis menyuarakan slogan yang tidak berdasar yang menyatakan bahwa suara perempuan merupakan aurat lantas bagaimana caranya agar perempuan dapat belajar dan mengembangkan kemampuan intektualnya jika tidak diperbolehkan untuk berbicara dan berkomunikasi kepada orang lain?

Hingga akhir periode zaman nubuwwah, antara kaum perempuan dengan lakilaki keduannya berperan sebagai subjek pendidikan. Masing-masing sebagai pendidik dan peserta didik, kesempatan belajar yang sama karena tanggungjawab yang sama pula. Hal tersebut terjadi karena Nabi tidak memecah-mecah persoalan ke-ummatan kepada perkara keagamaan dan keduniaan, perkara sosial dan individual, perkara perempuan dan laki-laki (Baidan, 1999: 37). Perbedaan tentu ada tetapi dalam batasbatas kewajaran tanpa menghilangkan aspek kebebasan asasi yang padanya melekat tanggungjawab asasi individu maupun sosial. Antara perempuan dan laki-laki memiliki kesempatan yang sama termasuk dalam hal seluruh otoritas keagamaan kecuali dalam peran kenabian dan kekhalifahan.

Sejarah menegaskan bahwa semasa Nabi Muhammad SAW masih hidup, hak memperoleh ilmu, kegiatan majelis ta'lim, dan aktif meriwayatkan hadist, bagi perempuan tidak pernah dilarang. Justru sebaliknya, Rasulullah sangat senang jika ada perempuan yang cerdas dan mampu kembali menyampaikannya pada orang 
lain. Sebut saja, A'isyah yang meriwayatkan ribuan hadist dan menjadi sumber informasi bagi kaum muslimin kala itu. Ada juga Fathimah bint al-Aqra‘, Syaikhah Syuhada, Zainab bint al-Syar'i, Rabi'ah al-Adawiyah, dan perempuan lainnya yang turut mewarnai khazanah keilmuan Islam (Roqib, 2003: 48). Namun, nama-nama tersebut sengaja dihilangkan dalam kesejarahan Islam. Sehingga saat membicarakan atau merujuk pemikiran tokoh-tokoh, maka yang hadir adalah tokoh-tokoh laki-laki dan perempuan menjadi tidak ada.

Hal tersebut mulai terlihat sejak zaman para tabi' tabiin. Tepatnya pada saat perumusan fiqh mengenai hak dan kewajiban perempuan dan laki-laki mulai gencar dirumuskan. Pada masa ini pula, lambat laut kiprah perempuan dalam pendidikan menjadi kabur dan lama-lama hilang. Terlebih, dalam rumusan fiqh perempuan dijadikan sebagai obyek yang dikontrol seksualitas dalam kehidupan sosial dan lainnya. Munculnya larangan perempuan keluar rumah tanpa didampingi mahram, keharusan isteri untuk taat patuh pada suami, larangan keluar rumah tanpa izin suami, pembatasan perempuan dalam percaturan politik negara, maupun larangan memimpin lainnya (Roqib, 2003: 49). Hal ini disalah artikan dengan batasbatas diluar kewajaran yang disyariatkan, sehingga hal ini cukup memberikan peluang untuk memarginalkan hak-hak perempuan.

Dalam firman-Nya telah dijelaskan tentang kedudukan laki-laki dan perempuan, di mana perempuan dan ;aki-laki adalah setara. Sebagaimana firman Allah dalam surat al-Baqarah/2 ayat 187), “Istri-istrimu adalah pakaianmu, dan engkau adalah pakaian mereka”. Pakaian dapat berfungsi sebagai pengganti untuk seseorang, dengan pakaian baru seorang mendapatkan kepribadian baru. Lebih jauh, pakaian dapat menyembunyikan tubuh, menutupi pandangan terhadap bagian-bagian yang bersifat pribadi dan melindungi pemakainya (Rusby, 2016:19). Hal ini memperlihatkan hubungan kesetaraan dalam kebersamaan dan betapa baiknya prinsip yang berlaku dalam perkawinan.

Menurut Abbas Karafat sebagaimana dikutip oleh Nashruddin Baidan (1999:39) mengatakan bahwa Nabi memerintahkan supaya memperhatikan 
pendidikan perempuan, sebagaimana penjelasannya:"Ibu bagaikan sekolah, bila anda mempersiapkannya secara baik, berarti anda telah mempersiapkan generasi bangsa dengan integritas kepribadian yang baik". Dengan demikian, Islam menginginkan laki-laki dan perempuan yang berbeda itu memperoleh pendidikan yang layak agar mereka memiliki pengetahuan yang seimbang sehingga mereka dapat berjalan seiring dalam berbagai aspek kehidupan.

Mengapa pendidikan perempuan penting? Karena perempuan, sebagaimana laki-laki, adalah manusia yang berhak mendapatkan pendidikan. Melalui pendidikan, ia akan dapat mengembangkan segenap potensi diri agar ia dapat meraih hidup yang lebih baik. Apalagi, dialah orang yang sejak dini mendidik anak-anak yang lahir dari rahimnya. Sudah umum diketahui dikalangan ilmuwan bahwa pengaruh pikiran dan emosi ibu sangat besar terhadap karakter anak yang dikandungnya (Mujiburrahman, 2014: 8-9). Ini berarti pendidikan ibu sudah terjadi sejak anak itu di dalam kandungan. Jika seorang ibu tidak pernah mendapatkan pendidikan, bagaimana mungkin kita mengharapkannya dapat mendidik anak-anak dengan baik? Itulah sebabnya mengapa kedudukan perempuan sebagai ibu sangat dihormati dalam tradisi Islam. Dalam Hadis diriwayatkan bahwa seorang sahabat bertanya pada Nabi SAW, kepada siapakah dia harus berbakti. Nabi menyebut 'Ibumu' sebanyak tiga kali, baru kemudian beliau menyebut 'Bapakmu'. Sedangkan ayat-ayat Alqur'an sepertinya cenderung menyebut kedua orangtua secara bersamaan, meskipun ada disebutkan secara khusus mengenai jasa ibu yang besar pada anak karena seorang ibu bersusah payah ketika mengandung dan menyusui selama dua tahun (QS Luqman: 14).

Berdasarkan uraian di atas, membiarkan perempuan dalam kebodohan merupakan kezaliman karena membiarkan mereka tidak mengembangkan potensi negara. Perlakuan tersebut di samping akan merugikan potensi negara juga bertentangan dengan al-Qur'an dan sunnah. Pendidikan bagi perempuan semakin penting artinya bila dilihat dari tugas dan fungsinya, baik dalam masyarakat maupun dalam rumah tangga. Tugas-tugas tersebut mustahil dapat terlaksana dengan 
baik tanpa pendidikan yang baik. Tugas-tugas perempuan kian kompleks seiring dengan perkembangan IPTEK, maka pendidikan bagi perempuan mutlak adanya.

Perempuan yang tidak mendapatkan pendidikan membuat mereka tidak mampu menjalankan perannya, baik dalam keluarga maupun dalam masyarakat. Apabila perempuan terdidik dengan baik, niscaya pemerataan pendidikan telah mencapai sasaran. Oleh karena itu, ibu adalah pendidik pertama dan utama dalam keluarga. Bandingkan, jika hanya mendidik seorang laki-laki, maka pendidikan itu hanya untuk satu orang laki-laki saja. Akan tetapi, jika mendidik perempuan, maka sama saja dengan mendidik satu orang keluarga karena peran ibu. Kenyataan ini dapat dilihat di masyarakat bahwa kebanyakan anggota keluarga sukses dalam pendidikan lebih disebabkan oleh ketekunan ibu dalam mendidik anaknya. Oleh karena itu, ibu sebagai seorang pendidik harus berbekal berbagai ilmu pengetahuan dan keterampilan.

Maraknya krisis hubungan suami-istri yang usia pernikahannya pendek atau KDRT terjadi dalam keluarga, bukan hanya terjadi di kalangan masyarakat yang kurang berakhlak, tetapi masyarakat bermoral pun dapat mengalami krisis yang sama, apabila tingkat pendidikan dan pengalaman antara keduanya berbeda jauh (Rusby, 2016: 21). Oleh karena itu, dapat dipastikan bahwa semakin baik pendidikan perempuan akan semakin baik harkat dan martabatnya dan semakin baik moralitas bangsa maka dapat membantu mencerdaskan masyarakat bangsa sehingga dapat mewujudkan keberhasilan pembangunan, di samping lebih memanusiakan manusia dan menghargai kepada hak-hak orang lain.

\section{PANDANGAN PROGRESIF RAHMAH EL-YUNUSIYAH DALAM KEPEMIMPINAN SEBAGAI ULAMA PELOPOR PENDIDIKAN MUSLIMAH INDONESIA}

Berdasarkan uraian di atas itulah yang dijadikan landasan utama oleh Rahmah El-Yunusiyah, memperluas misi kaum modernis untuk menyediakan Sarana pendidikan bagi kaum perempuan yang akan menyiapkan mereka menjadi warga yang produktif dan muslim yang baik. Ia menciptakan wacana baru di Minangkabau, dan 
meletakkan tradisi baru dalam pendidikan bagi kaum perempuan di kepulauan Indonesia. Diniyah Putri adalah akademi agama pertama bagi putri yang di dirikan di Indonesia.

Tujuan Rahmah mendirikan pendidikan perempuan ini adalah untuk meningkatkan kedudukan kaum perempuan dalam masyarakat melalui pendidikan modern yang berlandaskan prinsip-prinsip Islam. Ia percaya bahwa perbaikan posisi kaum perempuan dalam masyarakat tidak dapat diserahkan kepada pihak lain, hal ini harus dilakukan oleh kaum perempuan sendiri (Hamruni, 2004: 9). Melalui lembaga seperti itu, ia berharap bahwa perempuan bisa maju, sehingga pandangan lama yang mensubordinasikan peran perempuan lambat laun akan hilang dan akhirnya kaum perempuan pun akan menemukan kepribadiannya secara utuh dan mandiri dalam mengemban tugasnya sejalan dengan petunjuk agama.

Adapun cita-citanya dalam bidang pendidikan ialah: "Ia sangat ingin melihat kaum wanita Indonesia memperoleh kesempatan penuh menuntut ilmu pengetahuan yang sesuai dengan fitrah wanita sehingga dapat diamalkan dalam kehidupan seharihari dan mendidik mereka sanggup berdiri sendiri diatas kekuatan kaki sendiri, yaitu menjadi ibu pendidik yang cakap dan aktif serta bertanggungjawab kepada kesejahteraan bangsa dan tanah air, di mana kehidupan agama mendapat tempat yang layak" (Hamruni, 2004: 9). Selanjutnya cita-cita pendidikannya ini ia rumuskan menjadi tujuan perguruan Diniyah Putri yang didirikannya, yaitu: "Melaksanakan pendidikan dan pengajaran berdasarkan ajaran Islam dengan tujuan membentuk putrid yang berjiwa Islam dan Ibu Pendidik yang cakap, aktif serta bertanggungjawab tentang kesejahteraan masyarakat dan tanah air dalam pengabdian kepada Allah Swt”( Hamruni, 2004: 10).

Dalam perkembangan selanjutnya, sekolah ini menerapkan sistem pendidikan modern yang mengintegrasikan pengajaran ilmu-ilmu agama dan ilmu-ilmu umum secara klasikal, serta memberi pelajaran keterampilan. Meskipun demikian, ilmu-ilmu agama tetap menjadi pelajaran pokok dan merupakan kekhususan sekolah ini. Menurut Rahmah bahwa masyarakat bisa baik melalui rumah tangga sebab rumah tangga adalah 
tiang masyarakat dan masyarakat Tiang negara. Wanita adalah tiang rumahtangga, selain Adam, tiap manusia dilahirkan oleh wanita. Sebab itu ia menginginkan melalui pendidikan, setiap wanita menjadi ibu yang baik dalam rumahtangga, masyarakat dan di sekolah (Hamruni, 2004: 11).

Tujuan ini akan dapat dicapai bila kaum wanita mendapat pendidikan khusus dengan sistem tersendiri. Ia melihat bahwa hukum agama sangat erat sangkut pautnya dengan seluk beluk kewanitaan. Maka ia berkesimpulan perlu ada sebuah lembaga pendidikan khusus untuk anak-anak perempuan. Pandangan Rahmah ini menegaskan bahwa penyamaan pendidikan dan kurikulum antara pelajar putra dan putri bukanlah sesuatu yang bijak, karena keduanya memiliki karakter dan peran yang berbeda dalam masyarakat walaupun keduanya memiliki tanggung jawab yang sama.

Dalam dunia pendidikan, kontribusi Rahmah tidak hanya dengan mendirikan Diniyyah Puteri School saja, tetapi ia juga mendirikan beberapa sekolah lainnya, diantaranya:

1. Menyesal School, yaitu sekolah pemberantasan buta huruf di kalangan ibuibu rumah tangga. Sekolah ini didirikan pada tahun 1925 dan berlangsung selama tujuh tahun yaitu sampai tahun 1932. Kemudian sekolah ini tidak dilanjutkan. Untuk menyebarluaskan cita-cita pendidikannya, ia mengadakan perjalanan berkeliling ke daerah Sumatera Utara, Sumatera Selatan, Jambi dan Semenanjung Malaya (tahun 1928 dan tahun 1934).

2. Pada tahun 1935 ia mendirikan tiga buah perguruan putri di Batavia (Jakarta), yaitu di Kwitang, Jatinegara, dan di Tanah Abang. Pada masa pendudukan Jepang, perguruan tersebut tidak dapat diteruskan.

3. Yunior Institut Putri, sebuah sekolah umum setingkat dengan Sekolah Rakyat pada masa penjajahan Belanda atau Vervolgschool, didirikan pada tahun 1938. 
4. Islamitisch Hollandse School (HIS) setingkat dengan HIS (Hollandsch Inlandse School), yaitu sekolah dasar dengan bahasa pengantar bahasa Belanda.

5. Sekolah DAMAI (Sekolah Dasar Masyarakat Indonesia).

6. Kulliyatul Mu'allimin El-Islamiyah (KMI), yaitu sekolah Guru Agama Putra yang didirikan pada tahun 1940. KMI Putra ini didirikan untuk memenuhi kebutuhan masyarakat akan guru-guru agama putra yang banyak didirikan oleh masyarakat di Sumatera Barat. Keempat sekolah ini berhenti beraktivitas semenjak zaman penjajahan Jepang.

7. Pada tahun 1947 ia kembali mendirikan empat buah lembaga pendidikan agama putri dalam bentuk lain, yaitu Diniyah Rendah Putri (SDR), sekolah setingkat Sekolah Dasar dengan lama pendidikannya tujuh tahun,

8. Sekolah Diniyah Menengah Pertama Putri Bagian A Tiga Tahun (DMP Bagian A), Sekolah Diniyah Menengah Pertama Bagian B Lima Tahun (DMP Bagian B), dan Sekolah Diniyah Menengah Pertama Bagian C Dua Tahun (DMP Bagian C). Tiga buah sekolah yang disebut terakhir setingkat dengan Sekolah Menengah Pertama (SMP) dengan bidang studi agama dan bahasa Arab menjadi mata pelajaran pokok.

9. Akademi Diniyah Putri yang lama pendidikannya tiga tahun pada tahun 1964. Tanggal 22 November 1967 Akademi ini dijadikan Fakultas Dirasat Islamiyah dan merupakan fakultas dari Perguruan Tinggi Diniyah Putri. Fakultas ini "diakui" sama dengan Fakultas Ushuluddin Institut Agama Islam Negeri (IAIN) untuk tingkat Sarjana Muda (Susiyanto, 2014: 10).

Usaha-usaha yang dijalankan Rahmah El-Yunusiyah membuka dan mendirikan berbagai macam sekolah tersebut telah menempatkannya sebagai salah satu ulama wanita yang berpengaruh saat itu, khususnya di Padang Panjang dan Minangkabau pada umumnya, sehingga pantas dijuluki sebagai pelopor pendidikan perempuan diIndonesia. 
Pada tahun 1927, Rahmah pergi ke Sumatera Utara untuk mengumpulkan dana guna membangun sebuah gedung permanen yang baru. Gedung ini selesai di tahun berikutnya, yaitu sebuah bangunan dengan tujuh kelas. Untuk mencapai tujuannya Rahmah menganut sistem pendidikan terpadu, yaitu: memadukan pendidikan yang diperoleh dari rumah tangga, pendidikan yang diterima sekolah dan pendidikan yang diperoleh dari masyarakat di dalam pendidikan asrama. Dengan sistem terpadu ini, teori ilmu pengetahuan dan agama serta pengalaman yang dibawa oleh masingmasing murid dipraktekkan dan disempurnakan dalam pendidikan. Kurikulumnya terdiri dari kelompok bidang studi agama, bahasa Arab, ilmu pengetahuan dan kelompok bidang studi ini di orientasikan kepada pembentukan pribadi muslimah dan kualitas diri (Susiyanto, 2014: 12).

Independensi sekolah ini juga ditunjukkan saat diselenggarakan permusyawaratan besar guru-guru agama Islam se-Minangkabau yang ada di bawah Permi di Padang Panjang pada tahun 1931. Wakil dari guru Diniyah School Putra maupun Putri yang dating sebagai pendengar dan tidak member respons; tidak ada seorang pun dari guru-guru sekolah ini yang duduk di Dewan Pengajaran Permi yang bertugas untuk menyatukan pelajaran sekolah-sekolah Islam (Hamruni, 2004: 15).

Sebagai pemimpin Permi, Mukhtar Lutfi mempertanyakan hal tersebut. Rahmah pun mengemukakan pendapatnya, "Biarkan perguruan ini terasing selamalamanya dari partai politik, dan tinggalkanlah ia menjadi urusan dan tanggungan orang banyak (umum), sekalipun umum itu dalam aliran politiknya bermacam warna dan ragam, tapi untuk perguruan dan penanggung jawab atasnya haruslah mereka itu satu adanya". Lebih jauh independensi sekolah ini juga ditunjukkan Rahmah ketika dia menolak upaya penggabungan sekolah-sekolah Islam di Minangkabau oleh Mahmud Yunus. Seperti diketahui, pada tahun 1930-an ini pembaharuan sekolah agama berkembang pesat, namun tidak ada keseragaman program atau buku standar yang digunakan (Hamruni, 2004: 15).

Melihat keadaan ini Mahmud Yunus alumni Universitas Cairo yang saat itu menjadi Direktur Normal School, ingin menerapkan konsep pembaharuan 
pendidikannya dan memprakarsai pembentukan Panitia Islah al-Madaris al-Islamiyah Sumatera Barat. Namun Rahmah tetap teguh pada pendirian independensi sekolahnya, maka ia menolak keras ide itu. Dengan tegas dan bijaksana Rahmah menyatakan bahwa perguruannya akan berusaha dengan kekuatan sendiri menanggulangi berbagai kesulitan yang dihadapi (Hamruni, 2004: 16).

Sikap independen dan nonkooperatif tersebut, di samping menggambarkan cirri khas kepribadiannya yang gigih, juga merupakan respons terhadap situasi politik saat it u demi kelangsungan visi sekolahnya. Begitu pula organisasi kependidikan dan gerakan yang diprakarsainya, praktis visi yang sama: seperti "Perikatan Guru-Guru Agama Putri Islam” (PGAPI) yang didirikan pada tahun 1933 untuk menghimpun guru-guru yang tidak bergabung dengan Dewan Pengajaran Permi. Kemudian "Komite Penolakan Ordonansi Sekolah Liar” (1933) didirikan untuk menentang kebijaksanaan pemerintah colonial yang memberlakukan Ordonansi Sekolah Liar (1932) di Sumatera Barat (Susiyanto, 2014: 14).

Upaya-upaya Rahmah dalam mendirikan dan mengembangkan Diniyah School Puteri, yang bertujuan untuk mencerdaskan kaum perempuan mendapatkan perhatian secara khusus dari dunia Islam. Keberhasilan Rahmah ini menarik perhatian Syaikh Abdurrahman Taj, Rektor Universitas al-Azhar Cairo Mesir. Bahkan pada tahun 1955, Syaikh Abdurrahman mengadakan kunjungan ke sekolah yang terletak di Padang Panjang ini. Beliau tertarik dengan sistem pembelajaran khusus yang diterapkan kepada putri-putri Islam di Indonesia. Ia banyak menimba pengalaman dari sekolah yang didirikan Rahmah. Pada waktu itu, al-Azhar belum memiliki lembaga pendidikan khusus bagi kaum perempuan. Tak lama setelah kunjungan, Universitas Al Azhar membuka pendidikan khusus perempuan yang bernama kulliyyât al-banât (Susiyanto, 2014: 15).

Sebagai rasa terima kasih, Syaikh Abdurrahman mengundang Rahmah ke Universitas al-Azhar. Tahun 1957 Rahmah menunaikan haji, dan pulangnya mampir ke Kairo untuk menghadiri undangan Sang Rektor. Tak diduga sebelumnya, Rahmah ternyata mendapat anugrah berupa gelar Syaikhah oleh Universitas itu. Pemberian gelar 
ini belum pernah diberikan kepada siapa pun sebelumnya. Gelar yang baru disandangnya itu setara dengan gelar Syeikh Mahmoud Syalthout, salah seorang mantan rektor al-Azhar (Susiyanto, 2014: 15).

Keluarga yang memiliki latar belakang taat beragama dan aktif dalam gerakan pembaharuan menjadi ladang bagi bersemainya kesadaran pembaharuan dalam diri Rahmah. Ia menilai bahwa kaum perempuan sebagai tiang negara mestinya mendapatkan pendidikan yang baik sebagai halnya kaum lelaki. Keterbelakangan pendidikan kaum perempuan ini menurutnya berakar dari persoalan pendidikan dan melalui bidang ini dapat terselesaikan. Rahmah El-Yunusiah menulis:

"Diniyah School Puteri ini selalu akan mengikhtiarkan penerangan agama dan meluaskan kemajuannya kepada perempuan-perempuan yang selama ini susah mendapatkan penerangan agama Islam dengan secukupnya daripada kaum lelaki ... inilah yang menyebabkan terjauhnya perempuan Islam daripada penerangan agamanya sehingga menjadikan kaum perempuan itu rendam karam ke dalam kejahilan"(Hamruni, 2004: 19).

Jika kaum perempuan tidak mendapatkan ilmu yang memadai, maka bahaya akan datang dalam lingkungan masyarakat. Namun jika pendidikan yang diberikan kepada mereka itu keliru, maka tidak sedikit pula malapetaka yang akan menimpa bagi segenap masyarakat manusia. Berhubung dengan itu maka pendidikan terhadap kaum wanita hendaknya disertai dengan berbagai macam kebijaksanaan-kebijaksanaan, tidak boleh dilakukan secara serampangan. Oleh karena itu maka Rahmah El-Yunusiah berupaya untuk menggunakan landasan ideal dari pelaksanaa cita-citanya yaitu berpegang kepada Al-Qur’an dan As-sunnah. Pandangan Rahmah El-Yunusiah terhadap perempuan terlihat jelas bertolak dari ajaran Islam. Fakta sosial tentang adanya ketimpangan atau penindasan yang kadang terjadi di kalangan masyarakat Islam lebih banyak terjadi disebabkan oleh praktik dan tradisi masyarakat yang bersangkutan, ketimbang oleh ajaran Islam.

Rahmah menilai bahwa posisi kaum perempuan dalam Islam cukup sentral, dalam hal ini tidak ada perbedaan dengan kaum laki-laki. Perbedaan peran memungkinkan terjadi, namun hal ini bukan merupakan wilayah yang kemudian 
dijadikan pembenaran sebagai bukti adanya suatu diskriminasi. Ia hanya berupaya memperbaiki kondisi kaumnya melalui bidang pendidikan, sebab menurutnya wanita pada akhirnya akan berperan sebagai seorang ibu. Dan ibu merupakan madrasah awal bagi anak-anaknya sebelum terhubung dengan alam pandang (worldview) yang lebih luas di lingkungan sekitarnya. Melalui ibu inilah corak pandang dan kepribadian awal seorang anak akan terbentuk. Oleh karena itu menjadi penting bagi Rahmah untuk memberikan bekal bagi kaum perempuan ilmu-ilmu agama dan ilmu terkait lainnya sehingga bisa memiliki pengetahuan yang sama dengan mitra sejajarnya, kaum lelaki. Di sini pula akan terbentuk pandangan bahwa wanita merupakan tiang negara.

Usaha-usaha Rahmah El Yunusiah dalam memperjuangkan pendidikan untuk kaum perempuan, tidak diragukan lagi, bercorak agamis. Ia menggunakan ajaran Islam sebagai landasan perjuangannya. Al Qur'an dan Ash Shunnah ia tampilkan sebagai madah perjuangan yang harus diaplikasikan dalam gagasan dan aktivitasnya terkait bidang pendidikan. Dengan dasar agama ini pula ia ingin agar kaum perempuan bisa menjadi mitra yang sejajar bagi kaum lelaki dalam menjalani kehidupan berdasarkan ajaran Islam. Ia hanya menginginkan agar wanita mendapatkan posisinya sebagaimana ajaran Islam menempatkan kaum perempuan.

\section{PENUTUP}

Dari pembahasan di atas dapat di ambil berbagai kesimpulan terkait pribadi pejuang perempuan Rahmah El-Yunusiah sebagai berikut:

Pertama, Rahmah El-Yunusiah merupakan wanita yang pantang menyerah. Dalam kasusnya terkait akses kaum perempuan yang terbatas untuk menikmati dunia pendidikan. Ia sendiri hanya berhasil mendapat pendidikan dasar, namun kemauannya belajar dan keinginannya untuk memajukan kaumnya telah mengantarkan dirinya mampu menciptakan kesempatan bagi kaumnya untuk mendapat akses yang sama dengan kaum laki-laki dalam memperoleh ilmu pengetahuan.

Kedua, Rahmah El-Yunusiah adalah wanita pertama yang mendirikan sekolah khusus untuk kaum perempuan. Berkat prestasinya ini bahkan Universitas Al-Azhar tidak bisa tidak harus mengakui kepeloporannya dan mengikuti jejaknya dengan 
membuka program kulliyyât al-banât di Mesir. Ia juga merupakan orang yang pertama mendirikan layanan kesehatan (Rumah Sakit) khusus untuk kalangan perempuan.

Ketiga, Atas kiprah dalam lapangan keilmuan ia telah mendapat penghargaan yang selayaknya diperoleh. Ia mendapat gelar (honoris causa) "Syaikhah" dari Universitas Al-Azhar, Mesir atas perhatiannya dalam memajukan pendidikan kaumnya. Pemberian gelar ini belum pernah diberikan kepada siapa pun sebelumnya.

Keempat, corak perjuangan Rahmah El-Yunusiah bersifat agamis dimana ia menggunakan ajaran Islam sebagai dasar dan penegakannya menjadi cita-cita perjuangan. Dengan perjuangan ini ia mengharapkan kaum wanita akan bisa mengembangkan peran yang lebih baik sebagai mitra sejajar kaum pria. Peran perempuan bahkan cukup sentral dalam pembentukan awal sikap mental dan kepribadian generasi baru di lingkungan keluarga karena ia bergerak dalam wilayah domestik tersebut. Dalam ranah aktivitas yang lebih luas kaum perempuan pun tak kurang perannya. Penyiapan kaum perempuan secara kontinuitas akan membentuk mereka dalam menyiapkan kaum ibu sebagai tiang negara dan pendidik bangsa.

Dari kisah kehidupannya dapat diketahui bahwa Rahmah El-Yunusiah merupakan pejuang perempuan dengan motivasi yang tinggi dan pantang menyerah dalam memperjuangkan pendidikan kaum perempuan. Ia berjuang berdasarkan ideide yang ia yakini yang bersumber dari ajaran Islam yang berlandaskan Al Quran dan As-Shunnah. Pejuang tangguh selalu mewariskan nilai dan semangat yang bisa diteladani oleh generasi sesudahnya. Rahmah El-Yunusiah sendiri telah memberikan sebagian bukti bahwa harkat dan martabat manusia bisa terangkat ketika mereka menyadari tentang pentingnya ajaran agama diamalkan secara konsekuen. 


\section{DAFTAR PUSTAKA}

Abuddin Nata. (2005). Tokoh-tokoh Pembaruan dan Pendidikan Islam di Indonesia, Jakarta: Raja Grafindo Persada

Alim, A. S. (2016). Pendidikan Perempuan Di Indonesia Dalam Pemikiran Rahmah ElYunusiyah. Exposure Jurnal Fondasia 2008.

Baidan, N. (1999). Upaya Penggalian Konsep Wanita dalam Al-Qur'an. Yogyakarta: Pustaka Pelajar.

Ilyas, Y. (2006). Kesetaraan Gender dalam Al-Quran; Studi Pemikiran Para Mufassir (cet. ke-1). Yogyakarta: Labda Press

Isnaini, R. L. (2016). Ulama Perempuan dan Dedikasinya dalam Pendidikan Islam (Telaah Pemikiran Rahmah El-Yunusiyah). Jurnal Pendidikan Agama Islam, Volume 4 Nomor 1, ISSN(p) 2089-1946 \& ISSN(e) 2527-4511, Hal. 2 - 19.

Mantovani, S. L. (2015). Mendidik Tanpa Emansipasi (Refleksi Perjuangan Rahmah El-Yunusiyyah Dalam pendidikan). Jurnal Pemikiran Islam.

Muhammad, H., (2014). Perempuan Ulama Di Atas Panggung Sejarah: Bagian 1. Exposure Journal on Launching Buku dan Seminar Ulama Perempuan, Vol. 1, No. 4.

Mujiburrahman. (2014). Islam, Perempuan Dan Pendidikan. Exposure Journal marwah, Vol. XIII No. 1.

Nasution, K. (2001). Fazlurrahman Tentang Wanita. Yogyakarta: Tafazza.

Roqib. (2003). Pendidikan Perempuan. Yogyakarta: Gama Media dengan STAIN Purwokerto

Rusby, Z. (2016). Ketika Bias Gender Mengkristal; Mempertanyakan Peran Pendidikan Islam. Jurnal marwah, Vol. XV No.1.

Shihab, Q. (2004). Jilbab: Pakaian Wanita Muslimah, Jakarta: Lentera Hati

Shihab, Q. (2005). Perempuan, Jakarta: Lentera Hati

Susiyanto. (2014). Syaikhah Rahmah El-Yunusiah: Pendidik dan "Ibu Kandung Perjuangan". Islam Relitas: Journal of Islamic \& Social Studies Vol. 3, No. 1 